\author{
Editorial
}

\title{
One hundred years of academic forestry education in Estonian
}

The year 2020 marks the centenary of the establishment of the Department of Forestry at the University of Tartu in the Republic of Estonia, and thus the cradle of forestry education and forestry science in Estonian. These hundred years have witnessed rapid development, spurts, and swings as well as standstills and changes in direction.

Although the birth of the Department of Forestry was initiated by the sharp and urgent need of the young republic for educated forestry specialists, it was finally accomplished with the opening of the University of Tartu with Estonian as the language of instruction on December 1, 1919. Although the formation of the department at the newly-established national university in 1920 was a major undertaking, it laid a strong basis for systematic forestry research and experimental activities, and higher education in forestry in Estonia.

The establishment of the Department of Forestry brought about a rapid growth in the number of forest officers with higher education who applied their newly acquired knowledge and energy in domestic forestry. In addition to the training of forestry specialists, the Department of Forestry started to conduct national research in forestry, which quickly reached the international arena.

The generous early years of forestry education were followed by difficult years of war. Many forestry teachers and scientists either emigrated or they were arrested, or killed. The subsequent change in the state order inevitably left an irreplaceable imprint on forestry education and science.
Nevertheless, fresh hopes surged in 1951, when the Estonian Academy of Agriculture was established.

The revolutionary years after the restoration of independence also caused changes in academic forestry education. In recent decades, academic forestry education and science at the Estonian Agricultural University and the Estonian University of Life Sciences have been influenced by changes in society as well as general education and environmental policy.

The sustainability of modern forestry education and forest science in Estonian is proven by the fact that in the hundred years, 4,048 people have obtained a forestry specialist's diploma and a Bachelor's or Master's degree in Estonia. During this period, 83 forestry Master's theses, 67 candidate and 56 Doctoral theses have been defended. The work done in Estonia has received high recognition - in the international ranking of universities, the Estonian University of Life Sciences ranks among the fifty best universities in the world in the field of forest science and forestry education.

The increase in the number of young lecturers, the good quality of forestry education as well as the international scope of forest science in Estonia provide certainty that Estonian higher education in forestry will live, grow and flourish for the next hundred years as well.

\section{Ivar Sibul}

Chairman of the Organizing Committee of 100 Years of Academic Forestry Education 
Eessõna

\section{Sada aastat emakeelset akadeemilist metsandusharidust Eestis}

Tänavu möödub sada aastat päevast, kui Eesti Vabariigi Tartu Ülikoolis alustas tegevust metsaosakond, mida peetakse emakeelse metsandushariduse ja metsateaduse hälliks. Selle saja aasta sisse mahub kiiret arengut, spurte ja hoovõtte, aga ka seisakuid ja suunamuutusi.

Kuigi metsaosakonna sünni tingis noore vabariigi terav ja kiireloomuline vajadus haritud metsandusspetsialistide järele, sai see siiski teoks Eesti Vabariigi alguspäevil loodud emakeelse ülikooli avamisega Tartus 1. detsembril 1919. Ehkki vastloodud rahvusülikoolis ei olnud metsaosakonna asutamine 1920. aastal kerge ettevõtmine, rajas see tugeva baasi süsteemsele metsanduslikule uurimis- ja katsetegevusele ning metsanduslikule kõrgharidusele Eestis.

Tänu metsaosakonna loomisele suurenes kiiresti kõrgharidusega metsaametnike hulk, kes rakendasid oma värskelt omandatud teadmised ja energia kodumaa metsamajanduse teenistusse. Lisaks metsandusspetsialistide kasvatamisele alustati metsaosakonnas rahvusliku metsandusli$\mathrm{ku}$ teadusloomega, mis jõudis kiiresti ka rahvusvahelisele areenile.

Metsandushariduse viljakatele algusaastatele järgnesid keerulised sõja-aastad. Paljud metsandusõppejõud ja -teadlased emigreerusid kodumaalt, arreteeriti või nad hukkusid. Järgnenud riigikorra muutus jättis paratamatult korvamatu jälje ka metsandusõppele ja teadusele. Sellest hoolimata taasalustati uute lootustega vastses ülikoolis 1951. aastal, mil loodi Eesti Põllumajanduse Akadeemia.

Ka taasiseseisvumise pöördelised aastad tõid akadeemilisse metsandusharidusse suunamuutusi. Viimastel aastakümnetel on akadeemilist metsandusõpet ja -teadust Eesti Põllumajandusülikoolis ja Eesti Maaülikoolis mõjutanud nii muutused ühiskonnas kui ka üldine haridus- ja keskkonnapoliitika.

Tänapäeva emakeelse metsandushariduse ja metsateaduse kestvat head tervist näitab see, et saja aasta jooksul on Eestis metsandusspetsialisti diplomini ja bakalaureuse- või rakendusmagistrikraadini jõudnud 4048 eestimaalast. Metsanduslike teadusmagistritööde kaitsjaid on sel perioodil olnud 83, kandidaadi- ja doktoritöid on kaitstud vastavalt 67 ja 56 . Eestis tehtud töö on pälvinud ka kõrge tunnustuse - rahvusvahelises ülikoolide pingereas kuulub maaülikool nüüdsel ajal maailma viiekümne parima ülikooli hulka just metsateaduse ja metsandusõppe alal.

Noorte ôppejõudude juurdekasv ning Eesti metsateaduse ja metsandushariduse jätkuvalt hea tase ja rahvusvaheline haare annavad kindlust, et Eesti metsanduslik kõrgharidus elab, kasvab ja õitseb ka järgmised sada aastat.

\section{Ivar Sibul}

Metsanduslik kõrgharidus 100 korraldustoimkonna esimees 